\author{
Pure and Applied Chemical Sciences Vol. x, 20xx, no. xx, xxx - xxx \\ HIKARI Ltd, www.m-hikari.com
}

\title{
Curcumin restores glutathione-S-transferase activity for LNCaP prostate cancer cells
}

\author{
Vaibhav Dubey \\ School of Pharmacy and Pharmaceutical Science \\ Richard Owusu-Apenten* \\ School of Biomedical Sciences, University of Ulster Coleraine, \\ BT52 1SA, United Kingdom \\ *Corresponding author: email: r.owusu-apenten@ulster.ac.uk
}

Copyright (C) 20xx Vaibhav Dubey and Richard Owusu-Apenten. This is an open access article distributed under the Creative Commons Attribution License, which permits unrestricted use, distribution, and reproduction in any medium, provided the original work is properly cited.

\begin{abstract}
Prostate cancer is a leading cause of death in males aged fifty and over. Glutathione transferase (GST) activity is depressed in prostate cancer cells. The aim of this study was to assess GST reactivation in LNCaP prostate cancer cells treated with curcumin or 5-azacitidine (5-Aza) which is a known hypomethylation agent. GST activity was determined using monochlorobimane (MCB). Cell viability was assessed with resazurin (Vision blue TM) or 3-(4, 5-Dimethylthiazol-2-yl)-2, 5-di-phenyltetrazolium- bromide (MTT). From the results, treatment with $>5 \mu \mathrm{M}$ of curcumin or 5 -Aza for 3 or 6 days depressed LNCaP cell viability. The concentrations of curcumin leading to $50 \%$ reduction of LNCaP cell viability (IC50) was $10-25 \mu \mathrm{M}$ or $2-3 \mu \mathrm{M}$ for 3 days or 6 days of treatment, respectively. The IC50 with 5-Aza was $17-23 \mu \mathrm{M}$ (3 days) or 50-52 $\mu \mathrm{M}$ (6 days). Combination treatment using curcumin and 5-Aza showed complimentary interactions affecting cell viability. Low levels of curcumin or 5-Aza had no effect on GST activity. By contrast, cytotoxic doses of curcumin or 5-Aza increased GST activity by $450-750 \%$ (3days) or 161-2800 \% (6days). In conclusion, GST reactivation was feasible but only when $\mathrm{LNCaP}$ prostate cancer cells were treated with cytotoxic doses of curcumin or 5-azacytidne.
\end{abstract}

Keywords: Curcumin, 5-Azacytidine, prostate cancer, LNCaP, glutathione-Stransferase (GST), epigenetics. 


\section{Introduction}

Prostate cancer is the leading gender-specific cancer in males with $90 \%$ of cases occurring over the age 50 . The incidence of prostate cancer is higher in Western countries compared to South-Central-East Asian countries. Studies from developed countries suggest that males of black-African descent have a higher risk of developing prostate cancer as compared to their White and Asian colleagues [1]. Glutathione-S-transferase-pi (GST) expression is depressed in prostate tumors compared to benign prostate hyperplasia and normal prostate tissue due to gene silencing by epigenetic modifications [2, 3]. Hypermethylation affects GST expression, other tumor suppressor genes and various cancer-related processes: DNA repair, androgen responsiveness, cell cycle progression and metastases [4].

The GST superfamily comprises enzymes that protect healthy cells from reactive oxygen species (ROS), exogenous toxins, and cytotoxic agents. Inactivation of GST can create a deficit of detoxification capacity and increase tissue susceptibility towards carcinogens and ROS [5]. Restoration of GST activity was reported using 5-azacytidine (5-Aza; Vidaza ${ }^{\mathrm{TM}}$ ) or deoxy-5 deoxycytidine (Decitabine ${ }^{\mathrm{TM}}$ ) as hypomethylation agents $[6,7]$ though such drugs have significant side-effects [7, 8]. Dietary hypomethylation agents are now attracting attention in-part because of their expected lack of side-effects [9, 10] and potential for applications as nutraceuticals.

Curcumin (diferuloylmethane), the spice component from Curcuma longa (Turmeric), possess anticancer activity (for review see [11-13]. Curcumin impairs the growth and survival of androgen sensitive LNCaP and androgen independent DU145 prostate cells [14-18]. More recently, curcumin was identified as a dietary hypomethylation agent via docking simulations and cell-based assays [19]. Other investigations found also that GST expression increases following treatment of LNCaP cells with green tea phenol extracts, epigallogatechin gallate (EGCG) [20, 21], phenethyl isothiocyanate [22], selenium [23], genistein and daidzein [24, 25]. However, whether curcumin induces GST expression in prostate cancer cells has not been thoroughly studied. In the present investigation, it was hypothesized that treatment of LNCaP prostate cancer cells with curcumin would result in the reactivation of GST activity. The experimental design features curcumin comparison with 5-Aza as a known hypomethylation agent and positive control.

\section{Materials and Methods}

Curcumin ( $>98 \%$ pure), 5-Azacytidine (5-Aza: >98\% pure), monochlorobimane (MCB) , 3-(4,5-dimethyl thiazol-2-yl)-2,5-diphenyl tetrazolium bromide (MTT), Resazurin (Vision blue ${ }^{\mathrm{TM}}$ ), dimethyl Sulfoxide (DMSO) and other chemicals were obtained from Sigma-Aldrich and stored at temperature $\quad-20{ }^{\circ} \mathrm{C}$. 
Human prostate cancer cell lines (LNCaP) were obtained from American type cell culture collection. Cell culture medium RPMI $16401 \mathrm{X}$ (Stored at $1-5{ }^{\circ} \mathrm{C}$ ), Fetal bovine serum (FBS) (Stored at below $-5{ }^{\circ} \mathrm{C}$ ), Penicillin-Streptomycin solution (Stored at $1-5{ }^{\circ} \mathrm{C}$ ), Trypsin $1 \mathrm{X}$ (Stored at below $-18{ }^{\circ} \mathrm{C}$ ), and Phosphate Buffer Saline tablets were from GIBCO ${ }^{\circledR}$ Laboratories (Invitrogen Ltd, UK).

\section{Cell culture}

LNCaP prostate cancer cells were cultured using RPMI 1640 supplemented with 10\% FBS, $1 \%$ penicillin-streptomycin. Culture flasks and 96-well micro plates were incubated at $37{ }^{\circ} \mathrm{C}$ in a $5 \% \mathrm{CO}_{2}$ atmosphere (LEEC research incubator; LEEC, UK). All cell culture operations were performed in a laminar flow cabinet (Air flow service, UK). Cells were trypsinized, counted using a NucleoCounter (model NC-3000, ChemoMetec, Denmark) and seeded (10,000 cells/ well) in 96-microwell plates with $50 \mu \mathrm{l}$ of culture medium overnight at $37^{\circ} \mathrm{C}$ to allow attachment.

Curcumin and 5-Aza stock solutions $(10 \mathrm{mM})$ were prepared by dissolving with dimethyl sulfoxide (DMSO), diluting with culture medium 10-fold, and filter-sterilizing with $0.20-\mu \mathrm{m}$ cellulose acetate filters. The sterile solution of curcumin or 5 -Aza $(1.0 \mathrm{mM})$ was further diluted with culture media to obtain the concentrations of $0.1,1,10$, and $100 \mu \mathrm{M}$. Cells were treated with various concentrations of curcumin or 5-Aza $(0-100 \mu \mathrm{M} ; 50 \mu \mathrm{l})$ and incubated at $37^{\circ} \mathrm{C}$ for 3days or 6 days (72-144 hr). In these tests, the residual concentration of DMSO was $<0.5 \%$. For combination studies, cells were treated with a 50:50 mixture prepared from $20 \mu \mathrm{M}$ curcumin and $20 \mu \mathrm{M}$ of 5-Aza. Cells were treated with combination solutions which were $10 \mu \mathrm{M}$ with respect to curcumin and 5-Aza. All other techniques were as described previously.

\section{Multiplex fluorescence assay for LNCaP cell viability and GST status}

In this investigation, cell viability was determined using resazurin (Vision blue) as described by Ahmed et al. [26] and GST was determined essentially as described by Kamencic et al [27] with modification. For a multiplex fluorescence assay, cultured cells were washed three times with ice-cold PBS (100 $\mu 1)$ to remove growth media, 5-aza or curcumin. The wells were covered with 50 $\mu \mathrm{l}$ PBS and then $5 \mu \mathrm{l}$ of a 50:50 mixture resazurin and MCB was added to cells followed by $2 \mathrm{hr}$ incubation at $37^{\circ} \mathrm{C}$. Fluorescence readings were measured at excitation wavelength ( $\lambda$ ex) of $530-570 \mathrm{~nm}$ and emission wavelength $(\lambda \mathrm{em})$ of 590-620 for cell viability detection. A second set of fluorescence readings were also recorded with $\lambda \mathrm{ex}=360 \mathrm{~nm}$ and $\lambda \mathrm{em}=535 \mathrm{~nm}$ to detect the cellular GST activity. The fluorescence assays employed the Fluostar Omega Instrument (BMG-Lab-Tech, Germany).

\section{MTT assay for cell viability}

The MTT assay for cell viability was performed as described previously [28] with minor modification. Culture medium without / with curcumin or 5-Aza was 
removed by washing cells three times with ice-cold PBS (100 $\mu$ l) prior to addition of $20 \mu \mathrm{MTT}$. Then microwell plates were incubated for $2 \mathrm{hr}$ at $37^{\circ} \mathrm{C}$ and then treated with $100 \mu \mathrm{l}$ of lyses buffer (5\% sodium dodecyl sulfate in 50\% dimethyl formamide) for $24 \mathrm{hr}$ to dissolve the blue formazan crystals formed. Absorbance was measured at $570 \mathrm{~nm}$ using a microplate reader (Tuneable VERSA Max MTT Micro plate reader; Molecular Devices, USA).

\section{Statistical Procedures}

Data are expressed as mean \pm SEM of three independent experiments in case of curcumin and two independent experiments for 5-Aza. One-way ANOVA testing (SPSS) was used to analyze significant statistical differences with Tukey post hoc analysis. $\mathrm{P}<0.05$ were considered to be statistically significant.

\section{Results and Discussion}

The rate of development of prostate cancer is slow suggesting that this may be suitable for chemoprevention, by one of the following mechanisms: inhibition of phase I enzymes for carcinogens activation, induction of GST and other phase II enzymes for detoxification, and/ or modulation of cell-cycle progression, survival, apoptosis, angiogenesis or metastasis [10, 29, 30]. The enzyme GST is repressed in prostate cancer cells due to hypermethylation [2, 31-33]. Therefore, reactivation of GST is a potentially useful strategy for identifying hypomethylation agents [7]. In support of this thesis, several dietary agents were demonstrated to increase GST expression in LNCaP cells [20-25]. In view of recent reports concerning the role of curcumin as a hypomethylation agent [19], we examined the effect of this agent on cell viability and GST enzyme activity in LNCaP prostate cancer cells.

\section{Curcumin and 5-Azacytidine decrease LNCaP cell viability}

This study showed that curcumin and 5-Aza reduce LNCaP cell viability at concentrations $>5 \mu \mathrm{M}$ (Figure 1). LNCaP cell viability changes observed using the resazurin assay (Figure 1) were similar to those observed using the MTT assay (data not shown). The concentration of curcumin leading to $50 \%$ reduction of cell viability (IC50) is shown in Table 1 . For curcumin the IC50 values decreased with increasing treatment time. The IC50 for 3 days treatment (this study) agrees with 20-30 $\mu \mathrm{M}$ reported for $\mathrm{LNCaP}$ cells treated with curcumin for 3-days [14]; however, the IC50 was $50 \pm 9 \mu \mathrm{M}$ with two days of curcumin treatment [34]. The cytotoxicity of 5-Aza towards LNCaP cells has not been extensively studied. Thus, El Yagoobu found that $>5 \mu \mathrm{M}$ of 5-Aza was cytotoxic towards LNCaP cells but no IC50 values were reported [35]. Fesuccia et al showed that 5-Aza decreases LNCaP cell proliferation (IC50 $=1.5 \mathrm{mM}$ ) however the drug exposure time was not defined [36]. The IC50 value for 5-Aza (Table 1) are 100-fold higher compared to the IC50 reported for 5-aza-2'deoxycytidine [7] but the two drugs have differential modes of action. 
Combination studies were performed to determine whether treatment with a mixture of agents was advantageous compared with using curcumin or 5-Aza alone. Treatments using a mixture of curcumin and 5-Aza showed evidence of positive interactions at one day and 3 days exposure (Figure 2). At longer exposure times (6 days; 144hr) there was no difference in the cytoxicity of curcumin or 5-Aza alone or in combination (Figure 2).

Curcumin inhibition of LNCaP cell proliferation was time-dependent (Figure $1 \& 2$ ). Increasing the treatment time from 3 days to 6 days decreased the IC50 for curcumin by 10 -fold (Table 1). However, the IC50 value for 5-Aza increased by $\sim 2$-fold with increasing time of treatment. According to published data, LNCaP cell viability should decrease exponentially as a function of curcumin treatment time between $0-3$ days $[14,16]$. The time-course for LNCaP growth inhibition may also depend on the instability of curcumin. In buffer solution $(\mathrm{pH}$ 7.0) curcumin undergoes auto-oxidation with a half-life of 9.5 min increasing to 119 min at $\mathrm{pH} 3.0$ [37]. Dissolution with RPMI60 cell culture media containing $10 \%$ FBS raised the half-life of curcumin to $~ 8 \mathrm{hr}$ [37] and so $~ 90 \%$ of curcumin would oxidise in $24 \mathrm{hr}$ in the presence of culture media. It has been proposed that the anticancer activity of curcumin is due partly to one or more of its auto-oxidation products [38, 39].

\section{Curcumin and 5-Azacytidine increase GST activity from LNCaP cells}

The multiplex fluorescence assay for GST allowed adjustments for cell cytotoxicity (Figure 1) using resazurin fluorescence readings. Figure 3, shows that low doses of curcumin or 5-Aza produced no significant increases in the cell GST status. However, cytotoxic doses $(50 \mu \mathrm{M})$ of curcumin or 5-Aza produced significant increases in GST activity ( $\mathrm{P}<0.05$ ) of $450-750 \%$ (3 days) or $161-2800$ $\%$ (6 days). Cytotoxic doses (this study) or repeated low doses of nucleoside hypomethylation agents [31, 35] were required for reactivation of GST in LNCaP cells. Phytochemicals produce epigenetic or growth inhibitory effects depending on the concentration-time combinations used for treatment [23, 31, 35].

In conclusion, evidence presented in this study suggests that treating LNCaP prostate cancer cells with curcumin increases cellular GST activity. Analogous results were observed for LNCaP cells treated with 5-Aza which is an established hypomethylation agent. Cytotoxic doses of curcumin or 5-Aza were necessary for GST reactivation. The findings are similar to those reported for the induction of GST in breast cancer cells [40], as well as for phase II enzyme induction in other transformed cell lines [34]. Curcumin may function not only as a hypomethylation agent [19] but also as a "classical" chemopreventive agent via the Nuclear Factor-Erythroid 2-Related Factor 2 /antioxidant responsive element (Nrf2/ARE) pathway [16-18, 41]; detailed discussion of which mechanism predominates for curcumin bioactivity in LNCaP cells is beyond the scope of this paper though recent evidence suggests there may be cross-talk between the different pathways [42]. A chief limitation for this work is that there were no 
direct measurements of DNA-methylation. Further research is needed also into factors which determine the effectiveness of dietary hypomethylation agents.

\section{Acknowledgement}

VD is grateful to Mr. Virendra K Dubey and Mrs. Namrata Dubey for supporting his studies in the UK.

\section{References}

[1] Cancer Research UK (2014). Prostate Cancer, Available from http://www.cancerresearchuk.org/cancer-info/cancerstats/world/prostate-can cer-world/ (Accessed December 2013).

[2] Lee, W.H., Morton, R. A., Epstein, J. I., Brooks, J. D., Campbell, P. A., Bova G.S., Hsieh W.S., Isaacs W.B. \& Nelson W.G., Cytidine methylation of regulatory sequences near the pi-class glutathione-S-transferase gene accompanies human prostatic carcinogenesis. Proceedings of the National Academy of Sciences of the United States of America, 1994. 91(24): p. 11733-11737.

[3] Dumache, R., Motoc, M., Ionescu, D., Negru, S., Kaycsa, A., David, D., \& Puiu, M., Minimally invasive detection of prostate cancer by GSTP1 hypermethylation. Toxicology Letters, 2011. 211: p. S207-S207.

[4] Li, L.C., Okino, S. T., \& Dahiya, R., DNA methylation in prostate cancer. Biochimica Et Biophysica Acta-Reviews on Cancer, 2004. 1704(2): p. 87-102.

[5] Maruyama R., Toyooka S., Toyooka KO., Virmani A.K., Zöchbauer-Müller S., Aberrant promoter methylation profile of prostate cancers and its relationship to clinicopathological features. Clinical Cancer Research, 2002. 8(2): p. 514-519.

[6] Lin X., Asgari K., Putzi M.J., Gage W.R., Yu X., Cornblatt, B.S, Kumar A., Piantadosi, S., DeWeese, T.L., De Marzo, A.M., \& Nelson W.G., Reversal of GSTP1 CpG island hypermethylation and reactivation of pi-class glutathione S-transferase (GSTP1) expression in human prostate cancer cells by treatment with procainamide. Cancer Research, 2001. 61(24): p. 8611-8616.

[7] Chiam, K., Centenera, M.M., Butler L.M., Tilley W.D. \& Bianco-Miotto, T., GSTP1 DNA methylation and expression status is indicative of 5-aza-2'-deoxycytidine efficacy in human prostate cancer cells. PLoS One, 2011; 6(9):e25634.

[8] Christman, J.K., 5-Azacytidine and 5-aza-2 '-deoxycytidine as inhibitors of DNA methylation: mechanistic studies and their implications for cancer therapy. Oncogene, 2002. 21(35): p. 5483-5495.

[9] Li, Y. \& Tollefsbol, T.O., Impact on DNA methylation in cancer prevention and therapy by bioactive dietary components. Current Medicinal Chemistry, 
2010. 17(20): p. 2141-2151.

[10] Vanden Berghe, W., Epigenetic impact of dietary polyphenols in cancer chemoprevention: lifelong remodeling of our epigenomes. Pharmacological Research 2012. 65(6):p.565-576.

[11] Bar-Sela, G., R. Epelbaum, R. \& Schaffer, M., Curcumin as an anti-cancer agent: review of the gap between basic and clinical applications. Current Medicinal Chemistry, 2010. 17(3): p. 190-7.

[12] Epstein, J., Sanderson, I.R. \&. Macdonald, T.T., Curcumin as a therapeutic agent: the evidence from in vitro, animal and human studies. British Journal of Nutrition, 2010. 103(11): p. 1545-57.

[13] Sung B., Prasad S., Yadav, V.R. \& Aggarwal B.B., Cancer cell signaling pathways targeted by spice-derived nutraceuticals. Nutrition and Cancer, 2012. 64(2): p. 173-97.

[14] Dorai, T., Gehani, N. \& Katz, A., Therapeutic potential of curcumin in human prostate cancer - I. curcumin induces apoptosis in both androgen-dependent and androgen-independent prostate cancer cells. Prostate Cancer and Prostatic Diseases, 2000. 3(2): p. 84-93.

[15] Shankar, S. \& Srivastava, R.K. Involvement of Bcl-2 family members, phosphatidylinositol 3 '-kinase/AKT and mitochondrial p53 in curcumin (diferuloylmethane)-induced apoptosis in prostate cancer. International Journal of Oncology, 2007. 30(4): p. 905-918.

[16] Mukhopadhyay, A., Bueso-Ramos, C., Chatterjee D., Pantazis, P., \& Aggarwal B.B., Curcumin down regulates cell survival mechanisms in human prostate cancer cell lines. Oncogene, 2001. 20(52): p. 7597-7609.

[17] Chaudhury, L.R. \& Hruska, K.A., Inhibition of cell survival signal protein kinase B/Akt by curcumin in human prostate cancer cells. Journal of Cellular Biochemistry, 2003. 89(1): p. 1-5.

[18] Kumar A.P., Garcia G.E, Ghosh R., Rajnarayanan, R.V., Alworth, W.L. \& Slaga, T.J., 4-hydroxy-3-methoxybenzoic acid methyl ester: A curcumin derivative targets Akt/NF kappa B cell survival signaling pathway: Potential for prostate cancer management. Neoplasia, 2003. 5(3): p. 255-266.

[19] Liu Z., Xie, Z., Jones, W., Pavlovicz, R.E., Liu, S., Yu, J., Li, P.K., Lin J., Fuchs, J.R., Marcucci, G., Li C., \& Chan K.K.., Curcumin is a potent DNA hypomethylation agent. Bioorganic and Medicinal Chemistry Letters, 2009. 19(3): p. 706-9.

[20] Shukla, S., Trokhan, S., Resnick, J. I. \& Gupta, S. Epigallocatechin-3-gallate mediated reversal of GSTP1 CpG island hypermethylation leads to reactivation of GSTP1 expression in human prostate cancer cells. Cancer Epidemiology Biomarkers \& Prevention, 2004. 13(11): p. 1880S-1880S.

[21] Pandey, M., Shukla, S., \& Gupta, S. Promoter demethylation and chromatin remodeling by green tea polyphenols leads to re-expression of GSTP1 in human prostate cancer cells. International Journal of Cancer, 2010. 126(11): p. 2520-33. 
[22] Wang, L.G., Beklemisheva, A., Liu, X.M., Ferrari, A.C., Feng, J., \& Chiao, J.W. Dual action on promoter demethylation and chromatin by an isothiocyanate restored GSTP1 silenced in prostate cancer. Molecular Carcinogesis, 2007. 46(1): p. 24-31.

[23] Xiang, N., Zhao, R., Song, G., \& Zhong, W., Selenite reactivates silenced genes by modifying DNA methylation and histones in prostate cancer cells. Carcinogenesis, 2008. 29(11): p. 2175-81.

[24] Kikuno, N., Shiina, H., Urakami, S., Kawamoto, K., Hirata, H., Tanaka, Y., Majid, S., Igawa, M., \& Dahiya, R. Genistein mediated histone acetylation and demethylation activates tumor suppressor genes in prostate cancer cells. International Journal of Cancer, 2008. 123(3): p. 552-560.

[25] Vardi, A., Bosviel, R., Rabiau, N., Adjakly, M., Satih, S., Dechelotte, P., Boiteux, J.P., Fontana. L., Bignon, Y.J., Guy. L., \& Bernard-Gallon, D.J, Soy phytoestrogens modify DNA methylation of GSTP1, RASSF1A, EPH2 and BRCA1 promoter in prostate cancer cells. In Vivo, 2010. 24(4): p. 393-400.

[26] Ahmed, S.A., Gogal, Jr. R.M., \& Walsh, J.E. A new rapid and simple non-radioactive assay to monitor and determine the proliferation of lymphocytes: an alternative to [3H] thymidine incorporation assay. Journal of Immunological Methods, 1994. 170(2): p. 211-24.

[27] Kamencic, H., Lyon, A., Paterson, P.G., \& Juurlink, B.H., Monochlorobimane fluorometric method to measure tissue glutathione. Analytical Biochemistry, 2000. 286(1): p. 35-7.

[28] Price, P. \& McMillan, T.J. Use of the tetrazolium assay in measuring the response of human tumor cells to ionizing radiation. Cancer Research, 1990. 50(5): p. 1392-6.

[29] Singh, R.P. \& Agarwal, R. Mechanisms of action of novel agents for prostate cancer chemoprevention. Endocrine-Related Cancer, 2006. 13(3): p. 751-78.

[30] Syed, D.N., Khan, N., Afaq, F., \& Mukhtar, H. Chemoprevention of prostate cancer through dietary agents: progress and promise. Cancer Epidemiology, Biomarkers \& Prevention, 2007. 16(11): p. 2193-203.

[31] Lin, X., Tascilar, M., Lee, W.H., Vles, W.J., Lee, B.H., Veeraswamy, R., Asgari K., Freije, D., van Rees, B., Gage, W.R., Bova, G.S., Isaacs, W.B., Brooks J.D., DeWeese T.L., De Marzo A.M., \& Nelson W.G.., GSTP1 CpG island hypermethylation is responsible for the absence of GSTP1 expression in human prostate cancer cells. American Journal of Pathology, 2001. 159(5): p. 1815-1826.

[32] Singal, R., van Wert, J., \& Bashambu, M., Cytosine methylation represses glutathione S-transferase P1 (GSTP1) gene expression in human prostate cancer cells. Cancer Research, 2001. 61(12): p. 4820-4826.

[33] Nakayama, M, Gonzalgo, M.L, Yegnasubramanian S, Lin X, De Marzo A.M, \& Nelson W.G., GSTP1 CpG island hypermethylation as a molecular biomarker for prostate cancer. Journal of Cellular Biochemistry, 2004. 91(3): 


\section{p. $540-552$.}

[34] Brooks J.D., Goldberg M.F., Nelson L.A., Wu D., \& Nelson W.G., Identification of potential prostate cancer preventive agents through induction of quinone reductase in vitro. Cancer Epidemiology, Biomarkers \& Prevention, 2002. 11(9): p. 868-75.

[35] El Yaagoubi, M., Visvikis, A., Khalid, A., Siest, G., \& Wellman, M. 5-azacytidine modulates gamma-glutamyltransferase and glutathione levels in two human prostatic adenocarcinoma cell lines. Biochemistry and Molecular Biology International, 1998. 46(2): p. 321-331.

[36] Fesuccia C., D'Alessandro, A.M., Gravina, G.L., Biordi, L., Speca, S., Millimaggi, D., Dolo, V., Ricevuto, E., Vicentini, C., \& Bologna, M., Antiproliferative and pro-apoptotic effects of 5-azacytidine in prostate carcinoma cells in vitro involve the recovering of PTEN-mediated Akt activity control and androgen sensitivity. European Urology Supplements, 2007. 6(2): p. 83-83.

[37] Wang, Y.J., Pan, M.H., Cheng, A.L., Lin, L.I., Ho, Y.S., Hsieh, C.Y., Lin, J.K., Stability of curcumin in buffer solutions and characterization of its degradation products. Journal of Pharmaceutical and Biomedical Analysis, 1997. 15(12): p. 1867-1876.

[38] Gordon, O.N. \& Schneider, C., Vanillin and ferulic acid: not the major degradation products of curcumin. Trends in Molecular Medicine, 2012. 18(7): p. 361-363.

[39] Shen, L. \& Ji, H.F., The pharmacology of curcumin: is it the degradation products? Trends in Molecular Medicine, 2012 18(3): p. 138-144.

[40] Lam, Y. \& Owusu-Apenten, R. Enzyme induction and cytotoxicity of phenethyl isothiocyanate and its glutathione conjugate towards breast cancer cells. . Pure and Applied Chemical Sciences 2013 1: p 63-73.

[41] Lee, J.S. \&. Surh, Y.J., Nrf2 as a novel molecular target for chemoprevention. Cancer Letters, 2005. 224(2): p. 171-84.

[42] Khor, T.O., Huang Y., Wu T.Y., Shu, L., Lee J., \& Kong A.N., Pharmacodynamics of curcumin as DNA hypomethylation agent in restoring the expression of $\mathrm{Nrf} 2$ via promoter $\mathrm{CpGs}$ demethylation. Biochemical Pharmacology, 2010. 82(9): p. 1073-1078. 
Table 1: Inhibition of prostate cancer LNCaP cell growth by curcumin or 5-azacytidine for LNCaP prostate cancer cells

\begin{tabular}{lcc}
\hline & \multicolumn{2}{c}{ IC50 $(\mu \mathrm{M})$} \\
\hline Treatment time & CURCUMIN & 5-AZACYTIDINE \\
3 days & $10-25$ & $17-23$ \\
6 days & $2-3$ & $50-52$ \\
\hline
\end{tabular}

IC50 = Concentrations leading to 50\% decline in cell viability.
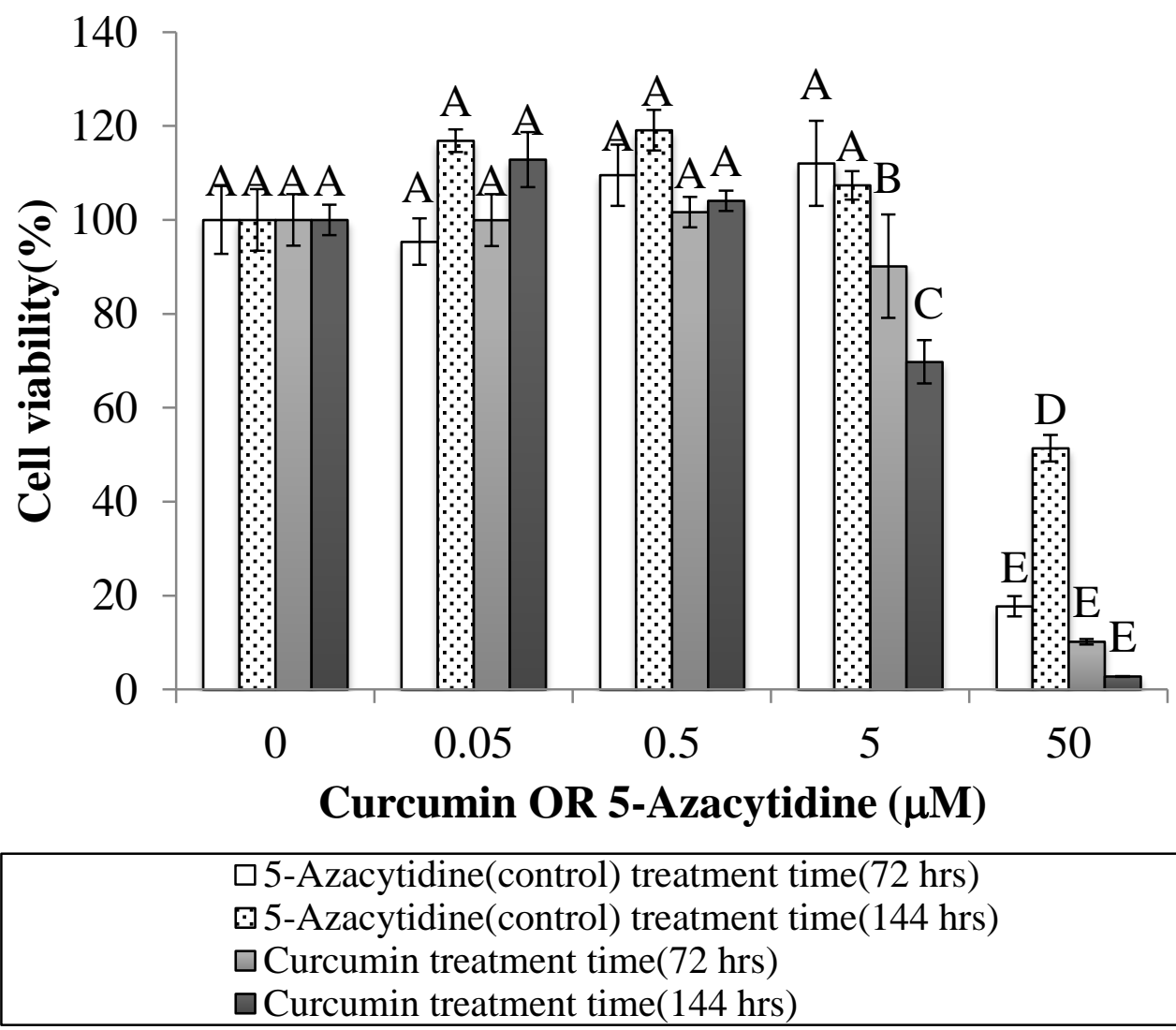

Figure-1: Effect of curcumin or 5-azacytidine on LNCaP cell viability. Data shows means \pm SE ( $n=12-16$ data points). Bars with different letters are significantly different $(\mathrm{P}<0.05)$. See text for details. 


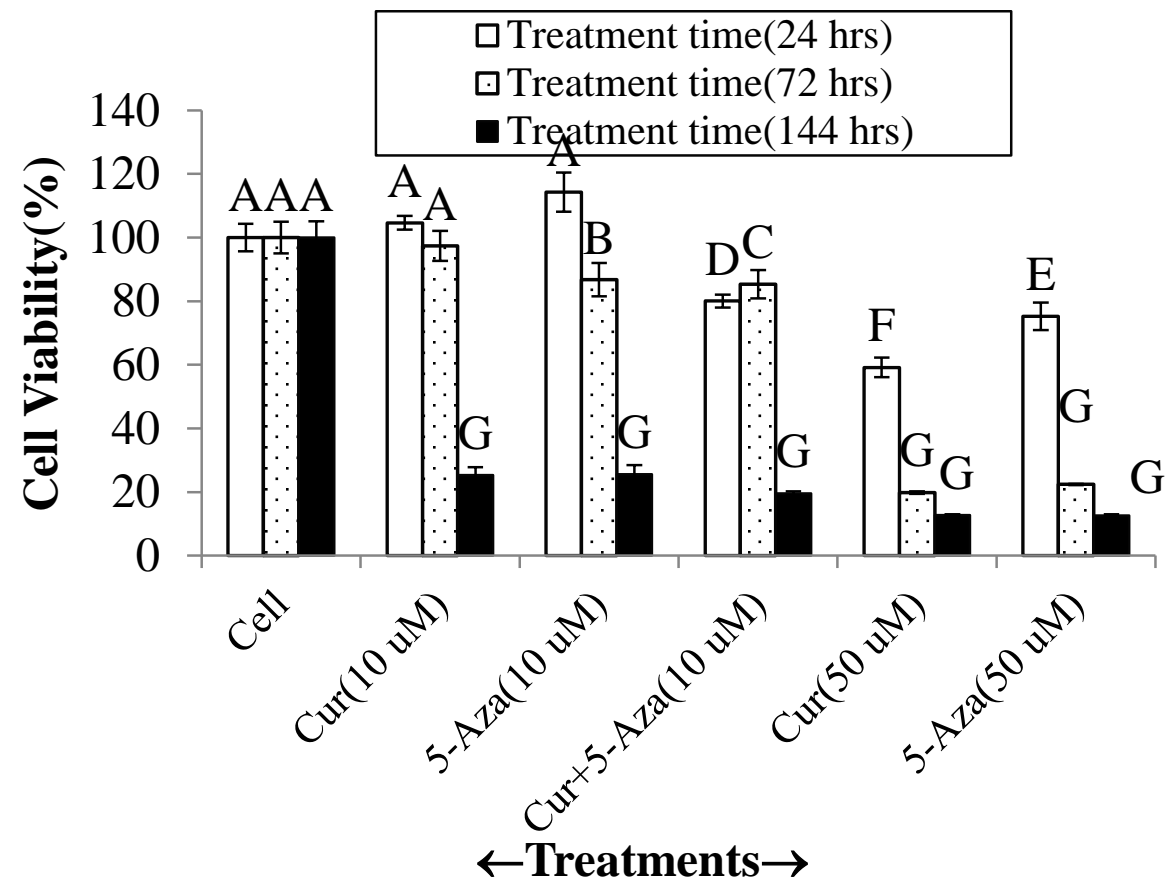

Figure-2: Effect of curcumin or 5-azacytidine or their combination on LNCaP cell viability. Bars with different letters are significantly different $(\mathrm{P}<0.05)$.

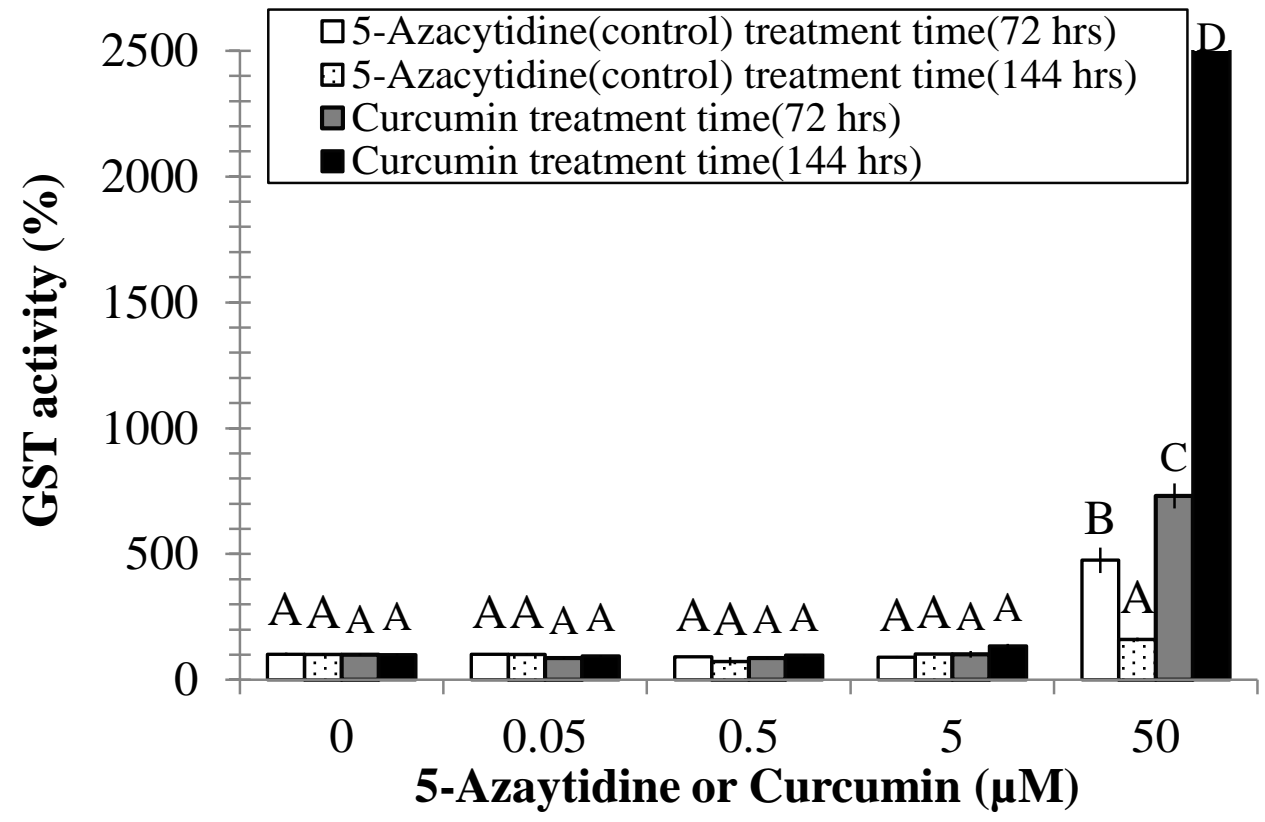

Figure 3: Effect of curcumin or 5-azacytidine on LNCaP glutathione-S -transferase (GST) activity. Bars with different letters are significantly different $(\mathrm{P}<0.05)$. See text for details.

Received: Month xx, 20xx 